\title{
Food-induced anaphylaxis in children - state of art
}

\section{Anafilaksja związana z pokarmem u dzieci - aktualny stan wiedzy}

\author{
1 Allergology and Pulmonology Department, Institute of Tuberculosis and Lung Diseases, Regional Branch in Rabka-Zdrój, Rabka-Zdrój, Poland \\ 2 Department of Pathophysiology, Medical College of Rzeszów University, Rzeszów, Poland \\ ${ }^{3}$ Paediatric and Allergology Department, Specialist Hospital, Jasło, Poland \\ ${ }^{4}$ Department of Paediatric Pneumonology, Department of Paediatrics No. 3, Medical University of Lodz, tódź, Poland \\ Correspondence: Łukasz Błażowski, Allergology and Pulmonology Department, Institute of Tuberculosis and Lung Diseases, Regional Branch in Rabka-Zdrój, Prof. Jana Rudnika 3B, 34-700 Rabka-Zdrój, Poland, \\ e-mail: I.blazowski@gmail.com
}

\begin{abstract}
Food-induced anaphylaxis is the most frequent type of anaphylaxis and the most common cause of fatal acute hypersensitivity reactions in children. It typically occurs after accidental food exposure, after inhalation of food allergen, cutaneous contact and controlled oral food challenge. There is no consensus on a universal clinical definition of anaphylaxis or a uniform symptoms severity score. Recent advances in molecular allergology allow, in many cases, the detailed identification of the allergenic molecule responsible for anaphylaxis. Along with the development of precision medicine, new phenotypes and endotypes of anaphylaxis are being defined. The anaphylaxis course is entirely unpredictable, and even initially mild symptoms may herald a potentially fatal reaction. At the same time, a significant proportion of immediate food hypersensitivity episodes are mild and known as systemic allergic reactions. The occurrence and severity of clinical course of food-induced anaphylaxis are influenced by factors related directly to the child, coexisting diseases, the type and the nature of the allergen, or the presence of cofactors. The unpredictable course of anaphylaxis justifies immediate treatment based on rapid intramuscular administration of adrenaline, regardless of severity. Delayed adrenaline administration is associated with higher incidence of severe course and death. Appropriate and prompt treatment of anaphylaxis is even more critical during the COVID-19 pandemic due to difficult access to medical facilities, hence current treatment plans for food-induced anaphylaxis emphasise the need to administer adrenaline immediately after the onset of the first, even mild, but rapidly progressive symptoms and recommend that the patient have at least two adrenaline autoinjectors.
\end{abstract}

Keywords: food-induced anaphylaxis, COVID-19, endotype, phenotype, allergen molecules

Streszczenie Anafilaksja związana z pokarmem jest najczęstszą formą anafilaksji oraz najczęstszą przyczyną zgonu z powodu ostrej reakcji nadwrażliwości u dzieci. Występuje najczęściej po przypadkowym spożyciu pokarmu, w wyniku inhalacji alergenu pokarmowego rozproszonego w powietrzu, po kontakcie alergenu ze skórą, a także w trakcie wykonywania prób prowokacyjnych z pokarmem. Obecnie nie ma zgodności co do uniwersalnej, klinicznej definicji anafilaksji, jak również jednolitej skali oceniającej stopień ciężkości jej przebiegu klinicznego. Ostatnie osiągnięcia diagnostyki molekularnej w alergologii pozwalają w wielu przypadkach na szczegółowe rozpoznanie cząsteczki alergenowej odpowiedzialnej za wystąpienie anafilaksji. Wraz z rozwojem medycyny precyzyjnej definiowane są nowe fenotypy i endotypy anafilaksji. Przebieg anafilaksji jest całkowicie nieprzewidywalny i nawet początkowo łagodne objawy mogą zwiastować reakcję potencjalnie śmiertelną. Jednocześnie znaczną część natychmiastowych epizodów nadwrażliwości na pokarm stanowią reakcje łagodne, określane jako systemowe reakcje alergiczne. Na wystąpienie oraz ciężkość przebiegu klinicznego anafilaksji pokarmowej wpływają czynniki związane bezpośrednio z organizmem dziecka, choroby współistniejące, rodzaj i właściwości samego alergenu czy też obecność kofaktorów. Nieprzewidywalność przebiegu reakcji anafilaktycznej uzasadnia konieczność natychmiastowego leczenia, którego podstawę stanowi szybkie domięśniowe podanie adrenaliny, niezależnie od stopnia ciężkości anafilaksji. Opóźnienie w podaniu adrenaliny wiąże się z większym ryzykiem ciężkiego przebiegu i zgonu. Właściwe i szybkie leczenie anafilaksji jest jeszcze bardziej istotne w okresie pandemii COVID-19, z racji utrudnionego dostępu do placówek medycznych, stąd w aktualnych wytycznych leczenia anafilaksji pokarmowej podkreśla się konieczność podania adrenaliny natychmiast po wystąpieniu pierwszych, nawet łagodnych, ale szybko postępujących objawów oraz zaleca się, aby chory posiadał przy sobie co najmniej dwie autostrzykawki lub ampułkostrzykawki $\mathrm{z}$ adrenaliną. 


\section{INTRODUCTION}

$\mathrm{F}$ ood-induced anaphylaxis (FIA) is the most common form of anaphylaxis in children, and the frequency of hospitalisation due to FIA, especially in the youngest children, increases at an alarming rate ${ }^{(1,2)}$. Food-induced anaphylaxis occurs mostly due to accidental food exposure (the most common allergen sources in Poland are cow's milk proteins, hen's egg protein, peanuts, tree nuts, sesame, fish, wheat), after inhalation of food allergen (fish, wheat, peanuts, tree nuts), after cutaneous contact (peanuts, tree nuts, fish, milk proteins, egg white) as well as during controlled oral food challenge (OFC).

The clinical definition of anaphylaxis should be the basis for diagnosis, however there is no consensus among experts on its universal tone ${ }^{(3-5)}$. There is also no uniform score of anaphylaxis clinical course severity, and the existing systems vary considerably ${ }^{(6-10)}$. On the other hand, due to the rapid development of component-resolved diagnostics (CRD) in allergology, a clear progress is observed in the recognition of the allergen responsible for the occurrence of the FIA. The evaluation of the immunoglobulin E (IgE) specific antibodies in relation to allergenic molecules (the proper allergens) in the main allergen source allowed for the differentiation of particular allergens in terms of the risk of developing severe anaphylaxis $^{(11)}$. In addition, CRD has contributed to the definition of new FIA phenotypes and endotypes, according to the assumptions of precision medicine, focused on an individual patient ${ }^{(11-15)}$.

Food-induced anaphylaxis is the leading cause of death due to an acute allergic reaction in children ${ }^{(16)}$. The course of anaphylaxis is completely unpredictable ${ }^{(17)}$ and even initially mild symptoms can herald a potentially fatal reaction $^{(18)}$. More than half of FIA deaths occurred in patients with previously mild reactions to food that caused fatal anaphylaxis. Simultaneously, a significant proportion of immediate episodes of food hypersensitivity are mild, usually self-limiting reactions with skin symptoms predominance, such as hives around the mouth, mild angioedema of the lips or eyelids, or mouth itching ${ }^{(15,19)}$. These reactions, defined as systemic allergic reactions $(\mathrm{SAR})^{(10)}$, usually pass without treatment, and without symptoms from other systems ${ }^{(20)}$. The evaluation of risk and severity of the FIA should always take into account the impact of factors directly related to the child (e.g. gender, age), concomitant atopy diseases such as asthma or atopic dermatitis, the type and properties of the allergen itself, and the impact of different anaphylactic cofactors $^{(17,21)}$.

The unpredictability of the anaphylactic reaction justifies the need for immediate treatment, the guiding principle of which is rapid intramuscular adrenaline administration in any case of diagnosed anaphylaxis, regardless of severity. An adrenaline administration delay is linked with a higher risk of severe anaphylaxis and death ${ }^{(18)}$. Proper and timely treatment of anaphylaxis is even more important during the COVID-19 (coronavirus disease 19) pandemic, due to the difficult access to hospital emergency departments, therefore, the current anaphylaxis treatment guidelines strictly emphasise the need for adrenaline administration immediately after the onset of the first, even mild symptoms, and it is recommended that the patient should carry at least two adrenaline autoinjectors or prefilled syringes ${ }^{(22)}$.

\section{EPIDEMIOLOGY OF FOOD-INDUCED ANAPHYLAXIS}

According to published epidemiological data, the FIA accounts for $30-50 \%$ of all cases of anaphylaxis, and in the paediatric population represents the vast majority of reactions ${ }^{(19)}$. Motosue et al. found that the majority of FIA occurred in the first 2 years of life, with a frequency of 20 cases per 100,000 children, while the largest increase in the number of FIA cases, by $413 \%$ $(p<0.001)$, during the study period (2005-2014) affected adolescents aged $13-17^{(19)}$. The most common cause of FIA among Polish children ( $0-18$ years) are allergens of cow's milk protein, peanuts, hen's eggs, tree nuts and grains. Food hypersensitivity deaths occur at any age, while in the paediatric population they account for the majority of anaphylaxis deaths. They occur most often after accidental ingestion of food, also described are cases of death during OFC (baked milk, peanuts), and even after skin exposure to milk proteins ${ }^{(16,23)}$. Despite the sharp increase in the incidence of FIA, in the recent years mortality rates are decreasing and, as indicated by Turner et al., it is estimated at 1.35-2.71 in million person-years ${ }^{(2)}$. The most frequent cause of death due to FIA are peanuts and tree nuts.

\section{CLINICAL DEFINITION OF ANAPHYLAXIS}

According to experts of the Polish Society of Allergology, anaphylaxis is a severe, potentially life-threatening, generalised or systemic hypersensitivity reaction ${ }^{(24)}$. The expanded definition, based on clinical symptoms, was published in 2006 by Sampson et al..$^{(3)}$ and it is still used in numerous publications, but raises objections from many experts ${ }^{(4,5)}$. Therefore, the proposed clinical definition of anaphylaxis is based on criteria published by experts from the World Allergy Organization ${ }^{(4)}$ and the Australasian Society of Clinical Immunology and Allergy ${ }^{(5)}$. According to this definition, food-induced anaphylaxis can be diagnosed if one of the two clinical criteria presented in Tab. 1 is met. When discussing acute allergic reactions after food intake, one should also define the SAR. As indicated by Cox et al., these are mild, slowly progressing reactions, from one system only and limited to skin/mucosal symptoms (urticaria, slight angioedema, erythema, itching), or 


\begin{tabular}{|c|c|}
\hline 1 & $\begin{array}{l}\text { Acute onset of the disease developing after exposure to the food } \\
\text { allergen, including: } \\
\text { - Skin/mucosal tissue symptoms (generalised hives, erythema, } \\
\text { itching, angioedema) } \\
\text { and } \\
\text { symptoms from one or more of the following systems: } \\
\text { - respiratory (shortness of breath, bronchospasm, swelling } \\
\text { in the throat/larynx) } \\
\text { - cardiovascular (decrease in blood pressure, dysfunctions associated } \\
\text { with the decrease in central nervous system tissue perfusion) } \\
\text { - gastrointestinal (persistent vomiting and/or severe crampy } \\
\text { abdominal pain) }\end{array}$ \\
\hline 2 & $\begin{array}{l}\text { Any sudden onset of hypotension* and/or sudden obstruction of the } \\
\text { lower and/or upper respiratory tract that occurred after exposure } \\
\text { to a food allergen, regardless of the presence of skin symptoms }\end{array}$ \\
\hline \multicolumn{2}{|r|}{$\begin{array}{l}\text { *A hypotension is defined according to the NIAID/FAAN (National Institute of Allergy } \\
\text { and Infectious Disease and Food Allergy and Anaphylaxis Network) } \\
\text { in children aged } 1-12 \text { month of age; }<70 \mathrm{~mm} \mathrm{~mm} \mathrm{Hg}+2 \times \text { age in years in children } \\
\text { from } 2 \text { to } 10 \text { years of age; }<90 \mathrm{~mm} \text { Hg in children }>10 \text { years of age. }\end{array}$} \\
\hline
\end{tabular}

Tab. 1. Clinical criteria for the diagnosis of food-induced anaphy$\operatorname{laxis}^{(3-5)}$

the gastrointestinal system (mouth itching, nausea, drooling) or upper respiratory tract (mild nasal/conjunctival symptoms, itchy throat) ${ }^{(10)}$.

\section{ANAPHYLAXIS SEVERITY GRADES}

Assessment of anaphylaxis severity determines the treatment methods and the way of dealing with the patient. Several tens of systems of anaphylaxis clinical assessment have been published so far, none of which is ideal and none has been validated in population-based studies ${ }^{(25)}$. The most well-known, widely used systems were published in chronological order by: Mueller $(1966)^{(6)}$, Ring and Messmer $(1977)^{(7)}$, Sampson $(2003)^{(8)}$, Muraro et al. $(2007)^{(9)}$ and Cox et al. (2017) ${ }^{(10)}$. Unfortunately, there are significant differences between them that make it difficult to uniformly assess the severity (Tab. 2). The reasons for these differences are multiple: (i) population heterogeneity, which was the basis for the assessment of a given scale; (ii) triggers of anaphylaxis, such as insect's venoms (Mueller), colloidal fluids (Ring and Messmer), food (Sampson), allergen immunotherapy (Cox et al.); (iii) the fact that some scales are based on expert opinion and others on clinical evaluation in the course of OFC; (iv) the different anaphylaxis definitions used during the individual systems development; (v) the fact that some scales cover only more significant symptoms, while others contain a wide range of symptoms, including mild systemic reactions; (vi) frequent occurrence of transposition of relevant clinical symptoms between the grades of particular systems, such as in terms of cardiovascular or respiratory symptoms ${ }^{(6,8,10)}$. Moreover, none of these systems is fully adapted to the real-life food-induced anaphylaxis severity assessment in a homogenous children population.

\section{THE DIAGNOSIS OF ANAPHYLAXIS TRIGGER}

The reference method for the diagnosis of IgE-dependent food allergy is controlled OFC. However, in the case of food-induced anaphylaxis, OFC is less important and may even be contraindicated for safety reasons ${ }^{(17,26)}$. Experts believe that the severity of clinical anaphylaxis during OFC does not reflect the clinical course of natural (real life) anaphylaxis, since OFC is always interrupted

\begin{tabular}{|c|c|c|c|c|}
\hline System & Clinical symptoms & Mueller, $1966^{(6)}$ & Ring and Messmer, $1977^{(7)}$ & Sampson, $2003^{(8)}$ \\
\hline \multirow{5}{*}{ Digestive } & Itching of the mouth & None & None & 1 \\
\hline & Nausea & II & II & $\|$ \\
\hline & Crampy abdominal pain & II & II & None \\
\hline & Persistent vomiting & II & III & III \\
\hline & Diarrhoea & None & III & IV \\
\hline \multirow{9}{*}{ Respiratory } & Nasal symptoms & None & $\|$ & $\|$ \\
\hline & Itching of the throat & None & None & III \\
\hline & Hoarseness & III & ॥ & IV \\
\hline & Swelling of the upper airways & III & III & IV \\
\hline & Stridor & None & None & IV \\
\hline & $\begin{array}{l}\text { Chest tightness/shortness } \\
\text { of breath }\end{array}$ & III & $\|$ & IV \\
\hline & Mild/moderate wheezing & II & III & IV \\
\hline & $\begin{array}{c}\text { Severe bronchospasm } \\
\text { of the lower airway }\end{array}$ & III & III & IV \\
\hline & Acute respiratory failure & IV & IV & V \\
\hline \multirow{4}{*}{ Cardiovascular } & Relevant hypotesion & IV & II & V \\
\hline & Pale and floppy child & None & None & None \\
\hline & Syncope & IV & None & None \\
\hline & Acute cardiovascular failure & IV & IV & V \\
\hline
\end{tabular}

Tab. 2. Main differences between the most common severity grading systems of clinical course of anaphylaxis (own elaboration) 


\begin{tabular}{|c|c|c|}
\hline Allergenic source & $\begin{array}{l}\text { Allergens associated with the risk } \\
\text { of developing anaphylaxis }\end{array}$ & $\begin{array}{l}\text { Allergens associated with the risk of developing } \\
\text { a systemic reaction or pollen-food syndrome }\end{array}$ \\
\hline Cashew nut & Ana 03 (albumin 2S) & \\
\hline Hazelnut & $\begin{array}{c}\text { Cor a } 8 \text { (nsLTP) } \\
\text { Cor a } 9 \text { (globulin 11S) } \\
\text { Cor a } 11 \text { (globulin 7S) } \\
\text { Cor a } 14 \text { (albumin 2S) }\end{array}$ & $\begin{array}{l}\text { Cor a } 1 \text { (Bet v } 1 \text { family) } \\
\quad \text { Cor a } 2 \text { (profilin) }\end{array}$ \\
\hline Walnut & $\begin{array}{l}\text { Jug r } 1 \text { (albumin 2S) } \\
\text { Jug r } 2 \text { (globulin 7S) } \\
\text { Jug r } 3 \text { (nsLTP) } \\
\text { Jug r } 4 \text { (globulin 11S) } \\
\text { Jug r } 6 \text { (globulin 7S) } \\
\end{array}$ & $\begin{array}{l}\text { Jug r } 5 \text { (Bet v } 1 \text { family) } \\
\text { Jug } r 8 \text { (profilin) }\end{array}$ \\
\hline Peanut & $\begin{array}{c}\text { Ara h } 1 \text { (globulin 7S) } \\
\text { Ara h } 2 \text { (albumin 2S) } \\
\text { Ara h } 3 \text { (globulin 11S) } \\
\text { Ara h } 6 \text { (albumin 2S) } \\
\text { Ara h } 7 \text { (albumin 2S) } \\
\text { Ara h } 9 \text { (nsLTP) } \\
\text { Ara h 14, } 15 \text { (oleosin) } \\
\text { Ara h 16, } 17 \text { (nsLTP) } \\
\end{array}$ & $\begin{array}{c}\text { Ara h } 5 \text { (profilin) } \\
\text { Ara h } 8 \text { (Bet v } 1 \text { family) }\end{array}$ \\
\hline Soya & $\begin{array}{c}\text { Gly m } 1 \text { (nsLTP) } \\
\text { Gly m } 4 \text { (Bet v } 1 \text { family) } \\
\text { Gly m } 5 \text { (globulin 7S) } \\
\text { Gly m } 6 \text { (globulin 11S) } \\
\text { Gly m } 8 \text { (albumin 2S) } \\
\end{array}$ & Gly m 3 (profilin) \\
\hline Sesame & $\begin{array}{l}\text { Ses and } 1 \text { (albumin 2S) } \\
\text { Ses and } 2 \text { (albumin 2S) } \\
\text { Ses and } 3 \text { (globulin 7S) } \\
\text { Ses and } 6 \text { (globulin 11S) } \\
\text { Ses and } 7 \text { (globulin 11S) }\end{array}$ & Ses i 8 (profilin) \\
\hline Wheat & $\begin{array}{c}\text { Tri a } 14 \text { (nsLTP) } \\
\text { Tri a } 19 \text { ( } \omega \text {-5 gliadin) } \\
\text { Tri a } 26 \text { (glutenin HMW) } \\
\text { Tri a } 36 \text { (glutenin LMW) } \\
\text { Tri a aA_TI (Tri a 15, 28, 29, 30) } \\
\text { Tri a gliadin (Tri a 19, 20, 21) } \\
\end{array}$ & Tria 12 (profilin) \\
\hline Kiwi & $\begin{array}{l}\text { Act d } 1 \text { (actinidin) } \\
\text { Act d } 2 \text { (TLP) } \\
\text { Act d } 5 \text { (kiwellin) } \\
\text { Act d } 10 \text { (nsLTP) } \\
\text { Act d } 12 \text { (globulin 11S) } \\
\text { Act d } 13 \text { (albumin 2S) } \\
\end{array}$ & $\begin{array}{l}\text { Act d } 8 \text { (Bet } v 1 \text { family) } \\
\quad \text { Act d } 9 \text { (profilin) }\end{array}$ \\
\hline Peach & $\begin{array}{c}\text { Prup } 2 \text { (TLP) } \\
\text { Pru p 3 (nsLTP) } \\
\text { Pru p } 7 \text { (gibberellin-regulated protein) }\end{array}$ & $\begin{array}{l}\text { Pru p } 1 \text { (Bet v } 1 \text { family) } \\
\text { Pru p } 4 \text { (profilin) }\end{array}$ \\
\hline Apple & $\begin{array}{c}\text { Mal d } 2 \text { (TLP) } \\
\text { Mal d } 3 \text { (nsLTP) }\end{array}$ & $\begin{array}{l}\text { Mal d } 1 \text { (Bet v } 1 \text { family) } \\
\text { Mal d } 4 \text { (profilin) }\end{array}$ \\
\hline Celery & $\begin{array}{l}\text { Api g } 2 \text { (nsLTP-1) } \\
\text { Api g } 6 \text { (nsLTP-2) }\end{array}$ & Api g 1 (Bet v 1 family) \\
\hline Tomato & $\begin{array}{l}\text { Sola I } 3 \text { (nsLTP-1) } \\
\text { Sola I } 6 \text { (nsLTP-2) } \\
\text { Sola I } 7 \text { (nsLTP-1) }\end{array}$ & $\begin{array}{l}\text { Sola I } 1 \text { (profilin) } \\
\text { Sola I } 4 \text { (Bet v } 1 \text { family) }\end{array}$ \\
\hline Cow's milk & $\begin{array}{c}\text { Bos d } 4 \text { (a-lactalbumin) } \\
\text { Bos d } 5 \text { ( } \beta \text {-lactoglobulin) } \\
\text { Bos d } 8 \text { (casein) }\end{array}$ & $\begin{array}{c}\text { Bos d } 2 \text { (lipocain) } \\
\text { Bos d } 6 \text { (serum albumin) } \\
\text { Bos d (lactoferrin) }\end{array}$ \\
\hline Chicken egg & $\begin{array}{l}\text { Gal d } 1 \text { (owomucoid) } \\
\text { Gal d } 2 \text { (ovalbumin) } \\
\text { Gal d } 4 \text { (lysozyme) }\end{array}$ & $\begin{array}{l}\text { Gal d } 3 \text { (ovotransferrin) } \\
\text { Gal d } 5 \text { (livetin) }\end{array}$ \\
\hline Cod & $\begin{array}{c}\text { Gad c } 1 \text { (parvalbumin) } \\
\text { Gad m } 1 \text { (parvalbumin) } \\
\text { Gad m } 2 \text { (enolase) } \\
\text { Gad m } 3 \text { (aldolase) }\end{array}$ & \\
\hline Prawn & $\begin{array}{c}\text { Pen } \mathrm{m} 1 \text { (tropomyosin) } \\
\text { Pen } \mathrm{m} 2 \text { (arginine kinase) } \\
\text { Pen } \mathrm{m} 3 \text { (light myosin chain) } \\
\text { Pen } \mathrm{m} 4 \text { (sarcoplasmic calcium-binding protein) } \\
\text { Cra c 6 (troponin C) }\end{array}$ & \\
\hline
\end{tabular}

Tab. 3. Food allergens (allergen molecules) associated with high risk of developing anaphylaxis, systemic reaction or pollen-food syndrome (own elaboration) 
at the first, usually mild symptoms, so it does not give the possibility to assess the full picture of FIA ${ }^{(23)}$. At the same time, a history of anaphylaxis to given food in the past does not determine the occurrence of anaphylaxis during $\mathrm{OFC}^{(26)}$.

In the case of demonstrating a clear-cut relation between exposure to a given food in the medical history and a clinical image of anaphylaxis, the diagnosis of the allergen responsible for the onset of FIA usually does not present difficulties. For final confirmation, allergen-specific $\operatorname{IgE}(\mathrm{sIgE})$ concentration is determined in relation to the allergen source and - taking into account the need and safety - skin prick tests and/or skin prick tests with native food allergens are carried out. However, even in the case of lack of certainty of the allergen source, the above tests do not provide an answer which allergenic molecule is responsible for triggering the FIA, and the precise determination of the allergen at the molecular level is extremely important to estimate the future risk on anaphylaxis. In addition, in many cases, the available history is not very clear. Often the patients ate several foods at the same time before the onset of symptoms, and sIgE studies in relation to the allergen source are not precise. Then it is necessary to use one of the methods of molecular diagnostics (CRD), through which sIgE can be determined in relation to allergen molecules, that is, the relevant allergens ${ }^{(27)}$. CRD not only gives the opportunity to accurately determine a specific allergen from many contained in a given allergen source, but also allows to assess the risk of anaphylaxis after another accidental exposure to an allergen or - in the case of a high degree of homology - to cross-reacting allergens ${ }^{(28)}$. A list of allergen molecules associated with high risk of developing severe systemic reactions or pollen-food allergy syndrome is presented in Tab. 3 .

\section{ANAPHYLAXIS PHENOTYPES}

Several anaphylaxis phenotypes have been described so far, but only depending on the time of onset (monophasic, biphasic anaphylaxis), on the allergen that triggered the reaction or on the severity of the reaction ${ }^{(13,14)}$. However, food-induced anaphylaxis is extremely heterogenous, resulting in a clinical picture which differs significantly not only between episodes in the same patient, but even in the case of the same trigger. The diversity of reactions is determined by many factors, such as different age of patients, different allergen dose, coexistence of other atopic diseases or the presence of cofactors ${ }^{(25)}$. It is therefore clear that there are currently no clinically useful predictive factors for severe anaphylaxis ${ }^{(15,17)}$.

Chong et al. believe that in the case of FIA different pathophysiological mechanisms are involved than in the case of anaphylaxis caused by other allergens and it is likely that there are phenotypes based on ste- clinical course ${ }^{(15)}$. Indeed, an analysis of 505 cases of food-induced anaphylaxis that occurred in the homogenous population of children aged 0 to 18 , treated at the Allergology and Pulmonology Department in RabkaZdrój ${ }^{(12)}$, showed that FIA episodes naturally group into two phenotypes (clusters) with different clinical severity and, more importantly, these studies confirm high stability during both phenotypes based on the clinical picture of the first episode of anaphylaxis (phenotype with mild symptoms is stable at $90 \%$, and phenotype with severe symptoms at $70 \%$ ). However, it should be remembered that despite the high repeatability of the FIA clinical images, the course of $10 \%$ and $30 \%$ of subsequent reactions respectively is completely unpredictable, hence the immediate administration of adrenaline is the basis for the treatment of any case of anaphylaxis, regardless of severity ${ }^{(18)}$.

\section{ANAPHYLAXIS ENDOTYPES}

Modern precision medicine, adapted to a particular patient, and its requirements make the determination of the endotype of the disease extremely desirable. Most anaphylactic reactions are mediated by IgE antibodies, although an alternative non-IgE-mediated pathomechanism is possible, consisting in the release of inflammatory mediators directly from mast cells and basophils or through complement activation. The last two mechanisms, mainly found in reactions following administration of drugs or radiocontrast media, are not entirely clear, and the main information comes from animal model studies ${ }^{(14)}$. In food-induced anaphylaxis, an endotype other than IgE-dependent constitutes an extraordinary rarity.

The unusual heterogeneity and unpredictability of anaphylaxis cause an intense search for endotypes which would allow for a prediction of a severe reaction. The authors' clinical studies based on molecular diagnostics allowed for the identification in a group of 237 children aged 0 to 18 the FIA endotype with the highest risk of severe course, which is monovalent sensitisation to Ana o 3, $2 \mathrm{~S}$ albumin derived from cashew nut, without concomitant sensitization to other food allergens ${ }^{(11)}$. The next few years will probably bring more information about other FIA endotypes.

\section{CLINICAL FACTORS OF SEVERE CLINICAL COURSE OF ANAPHYLAXIS}

Anaphylaxis - by definition - is a potentially fatal reaction, but most immediate episodes after food ingestion are mild or moderate ${ }^{(1,19,20)}$. They are dominated by skin symptoms (urticaria, self-limited angioedema) and mild gastrointestinal symptoms (itching of the mouth, nausea, drooling, single vomiting episodes). For the most part, these are self-limiting symptoms, which often disappear 


\begin{tabular}{|c|c|c|}
\hline \multicolumn{3}{|c|}{ Adrenaline $0.1 \%(1: 1,000): 1$ ampoule $=1 \mathrm{mg}=1 \mathrm{~mL}$} \\
\hline \multicolumn{2}{|c|}{ Dosage } & Comments \\
\hline \multicolumn{2}{|c|}{$\begin{array}{c}0.01 \mathrm{mg} / \mathrm{kg} \text { body weight } / \text { dose } \\
\text { Maximum single dose i.m. } \\
0.5 \mathrm{mg}\end{array}$} & INTRAMUSCULAR administration \\
\hline Body weight & Dose & \multirow{6}{*}{$\begin{array}{l}\text { - No dilution } \\
\text { - In the anterior-lateral surface of } \\
\text { the middle part of the quadriceps } \\
\text { muscle of the thigh }\end{array}$} \\
\hline $10 \mathrm{~kg}$ & $0.1 \mathrm{mg}=0.1 \mathrm{~mL}$ & \\
\hline $20 \mathrm{~kg}$ & $0.2 \mathrm{mg}=0.2 \mathrm{~mL}$ & \\
\hline $30 \mathrm{~kg}$ & $0.3 \mathrm{mg}=0.3 \mathrm{~mL}$ & \\
\hline $40 \mathrm{~kg}$ & $0.4 \mathrm{mg}=0.4 \mathrm{~mL}$ & \\
\hline $50 \mathrm{~kg}$ and more & $0.5 \mathrm{mg}=0.5 \mathrm{~mL}$ & \\
\hline
\end{tabular}

Tab. 4. Adrenaline dosage rules 1:1,000 (own elaboration)

\begin{tabular}{|c|c|}
\hline \multicolumn{2}{|c|}{ Prefilled syringe $0.3 \mu \mathrm{g} / 0.3 \mathrm{~mL}$} \\
\hline & Comments \\
\hline Adrenaline WZF $0.3 \mu \mathrm{g} / 0.3 \mathrm{~mL}$ & INTRAMUSCULAR administration \\
\hline $\begin{array}{l}\text { Adults and children } \geq 30 \mathrm{~kg} \text { body } \\
\text { weight (according to Summary } \\
\text { of Product Characteristics) }\end{array}$ & $\begin{array}{l}\text { - In the anterior-lateral surface of } \\
\text { the middle part of the quadriceps } \\
\text { muscle of the thigh }\end{array}$ \\
\hline \multicolumn{2}{|c|}{ Autoinjector } \\
\hline & Comments \\
\hline $\begin{array}{c}\text { EpiPen Jr } \\
0.15 \mathrm{mg} / \text { dose }\end{array}$ & INTRAMUSCULAR administration \\
\hline $\begin{array}{c}\text { Children from } 15 \mathrm{~kg} \text { to } 25 \mathrm{~kg} \\
\text { body weight }\end{array}$ & \multirow{3}{*}{$\begin{array}{l}\text { - In the anterior-lateral surface of } \\
\text { the middle part of the quadriceps } \\
\text { muscle of the thigh }\end{array}$} \\
\hline $\begin{array}{l}\text { EpiPen Senior } \\
0.3 \mathrm{mg} / \text { dose }\end{array}$ & \\
\hline Children $>25 \mathrm{~kg}$ body weight and adults & \\
\hline
\end{tabular}

Tab. 5. Adrenaline dosage in a prefilled syringe/autoinjector (own elaboration)

\begin{tabular}{|c|c|c|}
\hline \multicolumn{3}{|c|}{ Adrenaline 0.1\% (1:1,000): 1 ampoule $=1 \mathrm{mg}=1 \mathrm{~mL}$} \\
\hline $\begin{array}{c}\text { Method } \\
\text { of administration }\end{array}$ & $\begin{array}{c}\text { Method of preparation } \\
\text { of a solution that contains } \\
1 \mu \mathrm{gg} / \mathrm{ml}(1: 1,000,000) \\
\text { of adrenaline }\end{array}$ & $\begin{array}{c}\text { Rate of administration } \\
\text { of solution } 1 \mu \mathrm{g} / \mathrm{mL}\end{array}$ \\
\hline $\begin{array}{c}\text { Continuous } \\
\text { infusion i.v./i.o. }\end{array}$ & $\begin{array}{c}\text { Addition of } 1 \mathrm{mg}(1 \mathrm{~mL}) \\
\text { of adrenaline }(1: 1,000) \\
\text { to } 1,000 \mathrm{~mL} 0.9 \% \mathrm{NaCl}\end{array}$ & $\begin{array}{c}\mathrm{v}=0.1 \mathrm{~mL} \text { solution } / \mathrm{kg} \text { body } \\
\text { weight } / \mathrm{min}, \text { equivalent } \\
\text { to a dose } 0.1 \mu \mathrm{gg} / \mathrm{kg} \\
\text { body weight } / \mathrm{min}\end{array}$ \\
\hline
\end{tabular}

Tab. 6. Dosage and administration of adrenaline in slow intravascular/intraosseous infusion ${ }^{(5)}$

\begin{tabular}{|c|c|c|}
\hline \multicolumn{3}{|c|}{ Adrenaline 0.1\% (1:1,000): 1 ampoule $=1 \mathrm{mg}=1 \mathrm{~mL}$} \\
\hline $\begin{array}{c}\text { Method } \\
\text { of administration }\end{array}$ & $\begin{array}{c}\text { Method of preparation } \\
\text { of a solution that } \\
\text { contains } 20 \mu \mathrm{g} / \mathrm{mL} \\
\text { adrenaline }\end{array}$ & Solution dose $20 \mu \mathrm{g} / \mathrm{mL}$ \\
\hline & & $2 \mu \mathrm{g} / \mathrm{kg}$ body weight, \\
& & equivalent to a dose \\
& & $0.1 \mathrm{~mL}$ solution $/ \mathrm{kg}$ \\
body weight \\
Bolus i.v./i.o. & Addition of $1 \mathrm{mg}(1 \mathrm{~mL})$ & If no improvement: \\
& adrenaline $(1: 1,000)$ & $4 \mu \mathrm{m} / \mathrm{kg}$ body weight, \\
& to $49 \mathrm{~mL} 0.9 \% \mathrm{NaCl}$ & $\begin{array}{c}\text { equivalent to a dose } \\
0.2 \mathrm{~mL} \text { solution } / \mathrm{kg} \\
\text { body weight }\end{array}$ \\
\hline
\end{tabular}

Tab. 7. Dosage and administration of adrenaline in intravascular/intraosseous bolus ${ }^{(5)}$ without any treatment ${ }^{(20)}$. On the other hand, the unpredictability of the anaphylactic reaction determines the extreme caution in assessing the prognosis of a starting episode, which after a few minutes can become lifethreatening for the patient.

Various factors that could influence the severity of anaphylaxis were analysed: genetic predisposition, factors depending on the properties of the allergen or related to the patient himself (gender, age, the presence of other atopic diseases, such as asthma, or atopic dermatitis, hypersensitivity to many foods). The FIA is more common in boys, who also have a more severe clinical course ${ }^{(21)}$. Many studies highlight the higher risk of severe anaphylaxis - mainly associated with cardiovascular and central nervous system symptoms - in older children, especially adolescents, compared to infants and preschool children ${ }^{(12,19,29)}$. In contrast, ambiguous results relate to asthma as a risk factor for severe anaphylaxis. Although poorly controlled asthma significantly worsens the reaction itself ${ }^{(29)}$, major epidemiological studies have not confirmed a higher risk of severe clinical picture of anaphylaxis in patients with asthma ${ }^{(17,21)}$. There was no evidence of a relationship between atopic dermatitis and severe anaphylaxis ${ }^{(11,12,21)}$. Also, sensitisation and even an allergy to numerous foods do not seem to be a factor which increases risk of severe FIA. Conversely, the risk of such a reaction increases in the case of monovalent sensitisation, especially to essential allergen molecules (mainly $2 \mathrm{~S}$ albumin $)^{(11,12)}$. Many studies highlight the role of physical exercise as a risk factor for the severe course of the FIA $^{(12,16,21)}$.

\section{ANAPHYLAXIS COFACTORS}

In many cases, anaphylactic reactions would never have occurred had it not been for the factors (cofactors) that facilitated and accelerated their development. Among the most commonly mentioned cofactors are: physical exertion, alcohol, infection, menstruation and non-steroid anti-inflammatory drugs. In the case of children, by far the most important cofactor is physical exertion, especially intense, which can take place up to a few hours before or after eating food. Often, food containing a given allergen was previously tolerated by the patient, and anaphylaxis occurred only when food ingestion was accompanied by physical exercise.

The pathophysiology of food-dependent exercise-induced anaphylaxis (FDEIA) is not clear and theories about its development are not consistent. However, it is extremely important that FDEIA occurs mainly in older children and is mostly associated with a severe clinical course ${ }^{(12)}$. Allergens, which are often responsible for the onset of FDEIA, are wheat allergen Tri a 19 (omega-5-gliadin) and allergens from a family of non-specific lipid transfer proteins (nsLTP), found mainly in fruits, vegetables, tree nuts, legumes and grains ${ }^{(28)}$. 

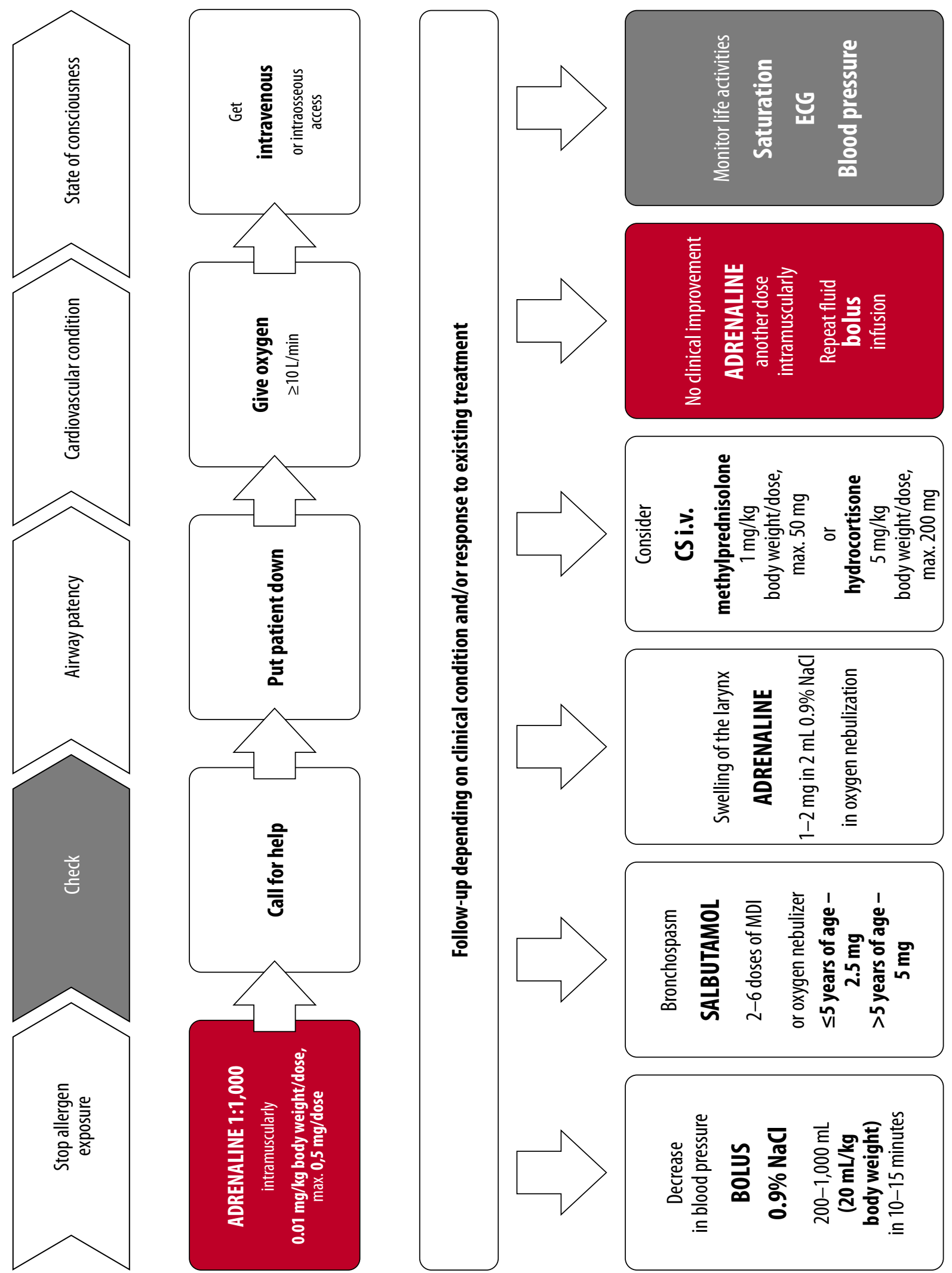

ECG - elektrocardiogram; CS - corticosteroids; MDI - metered dose inhaler.

Fig. 1. Algorithm of proceeding in anaphylaxis in children (own elaboration) 


\section{TREATMENT OF ANAPHYLAXIS}

Taking up the treatment immediately after diagnosis of an anaphylactic reaction is crucial for the life of the patient. Due to the unpredictability of the clinical course in any grade of anaphylaxis, adrenaline is recommended as the most important drug that reverses most of the pathomechanisms involved in its development. Any child at risk of FIA should be provided with adrenaline in the form of autoinjector or a prefilled syringe. Furthermore, in connection with the COVID-19 pandemic, which is associated with difficult access to medical facilities, the latest anaphylaxis algorithms stress the need to administer adrenaline immediately after the onset of the first, even mild, symptoms, and recommend that each patient with an allergy to important food allergens should receive not only one but at least two adrenaline autoinjectors $^{(22)}$.

Adrenaline is administered intramuscularly in the quadriceps muscle of the thigh, the anterior-lateral surface of its middle part. In the absence of clinical improvement, a second and third dose of intramuscular adrenaline is allowed at intervals of 5-15 minutes. If there are indications, further administration of adrenaline should be carried out by intravascular or intraosseous infusion (depending on the access gained) using an infusion pump, preferably in the conditions of an intensive care unit. In exceptional cases of cardiac arrest, during resuscitation, an intravascular adrenaline bolus can be administered. Doses of adrenaline i.m./i.v. and the rules of their preparation are presented in Tabs. 4-7. The rules of proceeding in anaphylaxis in children have been presented in an algorithm in Fig. 1. It should be remember that effective treatment of anaphylactic reaction is always based on teamwork with the requirement of periodic exercise of the rules of conduct together with the entire nursing and medical team ${ }^{(30)}$.

\section{Conflict of interest}

The authors do not report any financial or personal relationship with other persons or organisations that could adversely affect the content of the publication and claim the right to this publication.

\section{References}

1. Michelson KA, Dribin TE, Vyles D et al.: Trends in emergency care for anaphylaxis. J Allergy Clin Immunol Pract 2020; 8: 767-768.

2. Turner PJ, Campbell DE, Motosue MS et al.: Global trends in anaphylaxis epidemiology and clinical implications. J Allergy Clin Immunol Pract 2020; 8: 1169-1176.

3. Sampson HA, Muňoz-Furlong A, Campbell RL et al.: Second symposium on the definition and management of anaphylaxis: summary report - Second National Institute of Allergy and Infectious Disease/Food Allergy and Anaphylaxis Network symposium. J Allergy Clin Immunol 2006; 117: 391-397.

4. Turner PJ, Worm M, Ansotegui IJ et al.; WAO Anaphylaxis Committee: Time to revisit the definition and clinical criteria for anaphylaxis? World Allergy Organ J 2019; 12: 100066.

5. Australasian Society of Clinical Immunology and Allergy (ASCIA): Anaphylaxis Clinical Update 2016. Available from: https://www.allergy.org.au/images/ASCIA_HP_Guidelines_ Acute_Management_Anaphylaxis_2020.pdf [cited: 15 May 2020].

6. Mueller HL: Diagnosis and treatment of insect sensitivity. J Asthma Res 1966; 3: 331-333.

7. Ring J, Messmer K: Incidence and severity of anaphylactoid reactions to colloid volume substitutes. Lancet 1977; 1: 466-469.

8. Sampson HA: Anaphylaxis and emergency treatment. Pediatrics 2003; 111: 1601-1608.

9. Muraro A, Roberts G, Clark A et al.; EAACI Task Force on Anaphylaxis in Children: The management of anaphylaxis in childhood: position paper of the European academy of allergology and clinical immunology. Allergy 2007; 62: 857-871.

10. Cox LS, Sanchez-Borges M, Lockey RF: World Allergy Organization systemic allergic reaction grading system: is a modification needed? J Allergy Clin Immunol Pract 2017; 5: 58-62.e5.

11. Blazowski L, Majak P, Kurzawa R et al.: Food allergy endotype with high risk of severe anaphylaxis in children - monosensitization to cashew 2 S albumin Ana o 3. Allergy 2019; 74: 1945-1955.

12. Blazowski L, Jerzynska J, Kurzawa R et al.: Cluster analysis of 505 real-life food-induced anaphylaxis in children reveals two stable clinical phenotypes. Allergy 2021. DOI: 10.1111/all.14705.

13. Pouessel G, Dubus JC, Lejeune S et al.: Description of two anaphylaxis phenotypes in children: the utility of a clustering analysis approach. Allergy 2020; 75: 2671-2674.

14. Muraro A, Lemanske RF Jr, Castells M et al.: Precision medicine in allergic disease - food allergy, drug allergy, and anaphylaxis PRACTALL document of the European Academy of Allergy and Clinical Immunology and the American Academy of Allergy, Asthma and Immunology. Allergy 2017; 72: 1006-1021.

15. Chong KW, Ruiz-Garcia M, Patel $\mathrm{N}$ et al.: Reaction phenotypes in IgE-mediated food allergy and anaphylaxis. Ann Allergy Asthma Immunol 2020; 124: 473-478.

16. Pouessel G, Beaudouin E, Tanno LK et al.; Allergy Vigilance Network ${ }^{\text {: }}$ Food-related anaphylaxis fatalities: analysis of the Allergy Vigilance Network ${ }^{\circledR}$ database. Allergy 2019; 74: 1193-1196.

17. Turner PJ, Baumert JL, Beyer K et al.: Can we identify patients at risk of life-threatening allergic reactions to food? Allergy 2016; 71: 1241-1255.

18. Shaker MS, Wallace DV, Golden DBK et al.: Anaphylaxis - a 2020 practice parameter update, systematic review, and Grading of Recommendations, Assessment, Development and Evaluation (GRADE) analysis. J Allergy Clin Immunol 2020; 145: 1082-1123.

19. Motosue MS, Bellolio MF, Van Houten HK et al.: National trends in emergency department visits and hospitalizations for foodinduced anaphylaxis in US children. Pediatr Allergy Immunol 2018; 29: 538-544.

20. Turner PJ, DunnGalvin A, Hourihane JO: The emperor has no symptoms: the risks of a blanket approach to using epinephrine autoinjectors for all allergic reactions. J Allergy Clin Immunol Pract 2016; 4: 1143-1146.

21. Worm M, Francuzik W, Renaudin JM et al.: Factors increasing the risk for a severe reaction in anaphylaxis: an analysis of data from The European Anaphylaxis Registry. Allergy 2018; 73: 1322-1330. 
22. Casale TB, Wang J, Nowak-Wegrzyn A: Acute at home management of anaphylaxis during the Covid-19 pandemic. J Allergy Clin Immunol Pract 2020; 8: 1795-1797.

23. Grabenhenrich LB, Reich A, McBride D et al.: Physician's appraisal vs documented signs and symptoms in the interpretation of food challenge tests: the EuroPrevall birth cohort. Pediatr Allergy Immunol 2018; 29: 58-65.

24. Kruszewski J, Błażowski Ł, Grzelewska-Rzymowska I et al.: Anafilaksja. Stanowisko Panelu Ekspertów Polskiego Towarzystwa Alergologicznego. Medycyna Praktyczna, Warszawa-Kraków 2009.

25. Muraro A, Fernandez-Rivas M, Beyer K et al.: The urgent need for a harmonized severity scoring system for acute allergic reactions. Allergy 2018; 73: 1792-1800.

26. Turner PJ, Wainstein BK: Crossing the threshold: can outcome data from food challenges be used to predict risk of anaphylaxis in the community? Allergy 2017; 72: 9-12.
27. Błażowski Ł: Podstawy diagnostyki molekularnej w alergologii. In: Pawliczak R (ed.): Alergologia - kompendium. Termedia, Poznań 2018: 315-321.

28. Błażowski Ł, Kurzawa R: Wielokrotna, zależna od pokarmu anafilaksja indukowana wysiłkiem. Przydatność diagnostyki opartej na komponentach alergenowych. In: Kruszewski J (ed.): Analiza przypadków klinicznych w alergologii. Leczenie farmakologiczne w praktyce polskich lekarzy. Cz. II. PZWL, Warszawa 2018: 85-93.

29. Turner PJ, Jerschow E, Umasunthar T et al.: Fatal anaphylaxis: mortality rate and risk factors. J Allergy Clin Immunol Pract 2017; 5: 1169-1178.

30. Błażowski Ł, Rogala B, Cichocka-Jarosz E et al.: Anafilaksja. Sytuacje szczególne. Alergol Pol 2014; 1 Suppl 1: S1-S10. 